\title{
Effect of Celebrity Endorsement on Consumer's Perception of Corporate Image, Corporate Credibility and Corporate Loyalty \\ (Case Study: Novin Charm Company)
}

\author{
Bahareh Ghotbivayghan (Corresponding author) \\ Ershad Damavand University, Tehran, Iran
}

Tel: 98-21-6648-3602_E-mail: bahareghotbi2014@gmail.com

\author{
Masoomeh Hoseinzadehshahri \\ Alzahra University, Tehran, Iran \\ Tel: 98-21-8804-4040Ｅ-mail: mhshahri@yahoo.com
}

Mohammadreza Ebrahimi

Ershad Damavand University, Tehran, Iran

Tel: 98-21-6648-3602 E-mail: Mrebrahimi61@yahoo.com

Received: April 4, 2015 Accepted: April 27, $2015 \quad$ Published: May 8, 2015

doi:10.5296/csbm.v2i1.7385 URL: http://dx.doi.org/10.5296/csbm.v2i1.7385

\begin{abstract}
Nowadays, the use of celebrity endorsement in product marketing and advertising is one of the major factors in companies' promotion strategies. Celebrities as one of the major tools in advertising can lead to encourage consumers to use specific products and corporate loyalty because of their special and unique abilities or characteristics.

Study result show that the celebrity endorsement has a positive effect on corporate image, corporate credibility and corporate loyalty. Moreover corporate image have a positive effect on corporate credibility and corporate credibility have a positive effect on corporate loyalty.
\end{abstract}

Keywords: Celebrity endorsement, Corporate image, Corporate credibility, Corporate loyalty 


\section{Introduction}

Celebrities as the members in reference groups due to their unique and special abilities can persuade consumers to use special products. Kotler in his marketing management book has described the reference groups in this way: reference groups are developed from the groups who affect their behavioral beliefs in a direct or indirect way (Kotler, 2006). Celebrities have been recognized as the intellectual leaders who have the ability to conduct the consumers' preferences towards a special product or brand (Solomon et al., 2002). Efforts to acquire high levels of customer retention conduct the marketers to examine effect of celebrity on the consumer's understanding from the corporateimage, corporate trust and loyalty to the company. Concept of loyalty to company relates to the concepts such as corporate image and corporate trust.

\section{Literature Review}

The literature has suggested a number of concepts that may be used to assess the influence of celebrity attribute on corporate loyalty. In this study we selected four specific concepts: celebrity endorsement, corporate image, corporate credibility and corporate loyalty.

\subsection{Celebrity Endorsement}

Hundreds of studies into the role of celebrities have been undertaken in diverse fields including advertising, communication, psychology, medical care, marketing, politics, urban planning, economic behavior, and sport management. Previous research into the role of celebrities in advertisement include identification of the characteristics of effective celebrity spokespersons (Magnini et al., 2008) and the role of celebrity endorsement on destination image and intention to revisit (Lee et al., 2008). The effectiveness of advertising campaigns built on celebrity endorsement has attracted growing interest from researchers (Kim et al., 2013; Lin et al., 2008). Previous research has found that the impact of endorsement on factors including corporate image, credibility and loyalty are related to the type of celebrity used. Research into this issue has identified a core group of symbolic dimensions that determine the level of customer belief in celebrity endorsement including trustworthiness, expertise, personality, appearance, private life management, attractiveness, competency, relationship, ikeability, familiarity, identification (Amos et al., 2008; Han \& Ki, 2010). In relation to celebrity attributes a number of researchers have identified trustworthiness, expertise, and attractiveness as the most important attributes of celebrity endorsers (Amos et al., 2008; Han $\& \mathrm{Ki}, 2010$ ). Trustworthiness refers to the degree to which the audience perceives that the celebrity is able to convey a sense of integrity, honesty, and believability through the medium of advertising (Tripp et al., 1994). The second celebrity attribute is expertise, defined as the extent to which an individual's skill or experience, knowledge or expertnessis sought by others to assist in decision making (Amos et al., 2008; Lord \& Putrevu, 2009). Expertise is associated with competency, qualification, expertness, expert ability, mastery, and authoritativeness (Han \& Ki, 2010; Magnini et al., 2010). The third attribute is attractiveness defined as the sum of a celebrity's physical appearance, dress and accessories, beauty, elegance, sexual appeal, manners, and etiquette (Han \& Ki, 2010; Lord \& Putrevu, 2009). Insummary, previous research has found that physical features or images derived from the 
celebrity may be transferred to the productor company they endorse and as a consequence, affect corporate image or corporate credibility.

\subsection{Corporate Image}

Corporate image is the sum of the public's beliefs, ideas, and impressions of an organization (Bos, 2007). Thus, corporate image represents the unique and individual personality of a company that differentiates it from its competitors. Effective corporate image should also stimulate interest among customers, generates brand equity, and finally encourages sales (Amini et al., 2012; Kanibir \& Nart, 2009). Corporate image is shaped by a company's actions as well as by factors that have a direct or indirect impact on publicopinion, such as media, labor unions, social organizations, industrial associations, and other entities (Blishak, 2007). Customers' perceptions of corporate image are formulated by their response to a range of multifaceted tangible and intangible interactions with the corporation on a number of levels (Flavian et al., 2004). Tangible aspects include name, interior, exterior, products/services, displayed ambiences, and cyber communication vehicles. Intangible aspects include credibility, impression of quality, tradition, corporate philosophy, staff education, organization and service culture. Corporate image also reflects the needs or expectations of a diverse range of stakeholders who are directly or indirectly associated with the company (Lemmink et al., 2003). As aconsequence, corporate image may have different meanings based on the perceptions of stakeholders that include stockholders, boardmembers, employees, suppliers, channel members, customers and the community. Because diverse factors affect how corporate image is perceivedby stakeholders, most studies on dimensionality of corporate image suggested multidimensionality. They included community and environmental responsibility (Fatt et al., 2000), financial assurance (Lemmink et al., 2003), marketing and communication attributes (Dowling, 1993; Flavian et al., 2004), and quality of service/products (Fryxell \& Wang, 1994). Collectively, these studies indicate that corporate image directly determines corporate credibility (Amini et al., 2012). That is, favorable corporate image leads to heightened corporate credibility.

\subsection{Corporate Credibility}

Credible refers to "convincing", "reliable" or "believable" and is based on reputation, prestige and expertise (Collins Concise Dictionary and Thesaurus, 1995). From the corporate perspective, credibility is the extent to which consumers perceive that the company has the capability to implement management activities based on its knowledge, expertise, and trustworthiness. Most studiesthat have attempted to measure corporate credibility have used one dimension using items such as "expertise", "trustworthiness", "reputation", "reliability", "favorability", "pleasantness", “convincement” or "confidence” (Lafferty \& Goldsmith, 1999, 2004). Corporatecredibility is considered to be identical with celebrity credibility when celebrity endorsement is applied in corporate advertisement (Carlson \& Donavan, 2008). Corporate credibility contributes to building brand loyalty forits products or services and finally leads to enhanced sales (Ewin, 1993; Lafferty \& Goldsmith, 2004). In contrast, a lack of positive corporate credibility may result in a failure to achieve an increase in demand, brand preference or effective advertisement (Ketchen et al., 2008). As a result, a successful 
choice of celebrity endorsement will strengthen the brand image and then reinforce corporate credibility and finally generate an increase incorporate loyalty.

\subsection{Corporate Loyalty}

Loyalty to a company is a positive emotional attachment and emotional reaction which is created during repeated transactions with a company and its products and services (Ewin, 1993, 388-389). Creating corporate loyalty is an underpinning strategy for any company that seeks to increase profitability through seeking loyalty from customers and company employees (Ewin, 1993, p. 389). In this study, buyers can be viewed as stakeholders including customers, employees, shareholders or supporters of the Novin leather company. To enhance corporate loyalty, a company must be able to offer the consumer something that they feel is worthwhile. Once a potential customer expresses interest the company must be able to follow through with excellence or cost effectiveness to draw the consumer to the brand depending on how it fits their needs or wants. Corporate loyalty is reinforced by corporate credibility when the company provides good products or services (Ewin, 1993; Lafferty \& Goldsmith, 2004). In addition, it is also promoted by advertising using celebrity endorsement (Amini et al., 2012; Kim et al., 2013). As a result, enhanced loyalty through corporate credibility or advertising is reflected through intention to purchase or repurchase, recommendations to others, positive word-of-mouth, willingness to pay more and a reduction in complaints (Kim \& Kim, 2004; Ohanian, 1991).

\subsection{Moderating Impacts of Type of Celebrity}

A celebrity is characterized as a person who has attributes such as trustworthiness, attractiveness, and expertise (Amos et al., 2008; Han \& Ki, 2010; Lord \& Putrevu, 2009). Thus the effectiveness of advertising in capturing the consumers' mind is likely to differ based on the character of the endorser used. For example, select one handsome actor. His character evokes a sense of trustworthiness to movie viewers or consumers. Based on the findings of the literature it is apparent that the characteristics of the endorser, celebrity or otherwise, is an important element in the ability of the endorser to influence corporate image, corporate credibility, and corporate loyalty. Thus, the effectiveness of celebrity advertising in the sale and is likely to be influenced by the specific characteristics of the endorser used in advertising campaigns.

\section{Conceptualization and Hypotheses}

The following discussion examines these concepts and based on the outcome of the literature review a number of hypotheses were developed and tested.

\subsection{The Relationship between Celebrity Endorsement, Corporateimage, Corporate Credibility and Corporate Loyalty}

Based on previous studies (Amos et al., 2008; Kim et al., 2013), this study defines attributes of celebrity astrustworthiness, attractiveness, and expertise. Firstly, trustworthiness is an important attribute in clothing industry where the client frequently makes a booking without first seeing the product and forthis reason relies on the truthfulness of company marketing 
collateral, websites, word-of-mouth, advertisement or endorsement by acelebrity (Ketchen et al., 2008; Lin et al., 2008). According to 'match-up theory', advertising using a celebrity endorser influences consumer attitudes and their evaluation of the association between the celebrity on the company. Thatis, celebrity endorsement that promotes trustworthiness produces the best "fit" in generating positive customer views on the company's approach to social responsibility, its marketing ability, and provides assurance that the company is reliable (Kim et al., 2013). At the corporate level trustworthy celebrity endorsers are an effective means of communicating positive messages to customers about the company and its products, its contribution to society and corporate competency (Fink et al., 2012). Secondly, effective endorsement by an attractive celebrity has the potential to enhance corporate image by diluting negative attitudes toward the company including beliefs that the company is environment-oriented, effective for revenue-generation, competent for marketing (Amos et al., 2008). This view is supported by the 'symbolic communications model' which describes the process where qualities of the celebrity endorser are used to transfer qualities such as 'elegance', 'luxury', 'modernization' or 'fashionability' onto the company (Magnini et al., 2008; van der Veen, 2008). This modelis similar to the 'meaning-transfer model' where attributes of celebrity expressed as icons or symbols are transferred to the cognition system of consumers in a process of decoding meaning of these symbols (Lord \& Putrevu, 2009; van derVeen, 2008).

As a result, the characteristics of the celebrity are able to confercredibility to the company and enhance corporate loyalty (Lord \& Putrevu, 2009). The greater the perceived level of expertise the celebrity endorser is seen to have in the advertised product the more persuasive or effective the advertisement is likelyto be (Magnini et al., 2008, 2010). Where there is a successful connection between the celebrity and their perceived level of expertise in the product there is generally an increase in intention to purchase, in part based on the assurance given aboutservice quality (Amos et al., 2008; Kim et al., 2007). For example, some studies (Amos et al., 2008) describe how manufacturing companies are able to achieve a celebrity-transferred halo effect of 'professionalism', 'competency', 'mastership or 'state-of-the-art' technologyby using artisans as endorsers. Similarly, effective endorsement of companies with cutting-edge technology has generated increased corporate credibility and loyalty (Till \& Busler, 2000). In sum, the presence of a celebrity on a clothing advertisement hasthe effect of transferring the symbolic imagery of that celebrity to the company and through this process has the potential to increase corporate credibility of and corporate loyalty toward the companybeing endorsed. However it has also been found that the effects of celebrity attributes on corporate image, corporate credibility, and corporate loyalty is likely to differ according to the characteristics ofthe celebrity endorser. The review of the literature has identified a number of processes that govern the effectiveness of celebrity appeal on corporate image, corporate credibility and corporate loyalty and are listed below as a set of hypotheses.

Hypothesis 1. The personal characteristic of celebrity endorser is likely to have a positive effect on the corporate image.

Hypothesis 2. The personal characteristic of celebrity endorser is likely to have a positive 
effect on corporate credibility.

Hypothesis 3. The personal characteristic of celebrity endorser is likely to have a positive effect on corporate loyalty.

\subsection{Relationship of Corporate Image to Corporate Credibility}

On the basis of the previous review of the literature it is apparent that advertising using celebrity endorsement can be used toenhance company image and credibility through purging negative images attached to the company (Kanibir \& Nart, 2009; Tripp et al., 1994). These findings are consistent with those of previous studies that demonstrated a positiverelationship between celebrity endorsement and corporate imageas an antecedent to increase brand credibility (Stallen et al., 2010). A company endorsed by celebrity advertisement as being asocially responsible organization also reinforces corporate credibility (Stallen et al., 2010). For example, corporate advertising that emphasizes contribution to society by utilizinga social activist endorser is able to enhance corporate credibility because consumers tend to support companies that adopt socially responsible management policies (Han \& Kim, 2010). Similar observations have been made in the business press and the academic literature that the halo effect of celebrity is able toenhance corporate credibility (Fink et al., 2012). If a mismatch or an inconsistency between the celebrity attributes and those of the endorsed company occurs, a number of adverse effects can be expected including a loss of credibility and also of customers (Amos et al., 2008). Celebrity endorsement is also likely to be an antecedent toenhanced corporate credibility (Wang et al., 2002). Tiger Woods, a well-known professional golfer is an example of how a fall in popularity of a successful endorser due to scandals involving alleged extramarital affairs resulted in the loss of a number of large endorsement business contracts. Nike signed a five-year contract with Woods fora fee of approximately US\$105 million in 2000 (Farrell et al., 2000). The successful match of Woods with Nike resulted in substantial financial gains for both parties as well as engendering psychological credibility on the brand. However, the alleged scandals resulted in Woods temporarily withdrawing for golf. Many of the firms that had used Wood's image as an integral part of their advertising including AT\&T, Accenture and Gillette withdrew their endorsement fearful that declining public trust in Wood's image would translate into a decline in trust of their products (Grocer, 2009). Consequently, when celebrity endorsement is used to build a firm's corporate image, the firm's credibility is then linked to that image.

Hypothesis 4. Corporate image is likely to have a positive effect on corporate credibility.

\subsection{Relationship of Corporate Credibility to Corporate Loyalty}

As previous studies using the 'meaning-transfer model' indicate, attributes of celebrity endorsement are transferred to consumer's self after he/she is exposed to corporate advertising (Lord \& Putrevu, 2009; van der Veen, 2008). As the 'symbolic communications model' indicates, corporate credibility that has been enhanced by celebrity endorsement contributes to the strengthening of corporate loyalty (Stallen et al., 2010). The influence of corporate credibility on corporate loyalty through the 'halo effect' of celebrity endorsement can be confirmed by the 'match-up theory' which postulates a positive a relationship between 


\section{Macrothink}

the endorser and the brand. Corporate credibility, when enhanced through effective endorsement, helps to create a positive brand attitude such as intention to purchase and brand loyalty (Carlson \& Donavan, 2008). The relationship between corporate credibility and corporate loyalty can be ascertained by the advertising 'schema theory' which argues that a hypothetical memory structure helps consumers to organize and accept new promotional information based on prior experience or conventional wisdom (Carlson \& Donavan, 2008; Fink et al., 2012). For this reason company credibility will be adversely affected by a decline in the trustworthiness of a celebrity endorser because of the creation of a negative link between brand credibility and loyalty. Changes in company credibility created by endorsement can be measured by proxy variables such as intention to purchase or positive recommendations. Based on this review of the relevant literature the following hypothesis was developed.

Hypothesis 5. Corporate credibility is likely to have a positive effect on corporate loyalty.

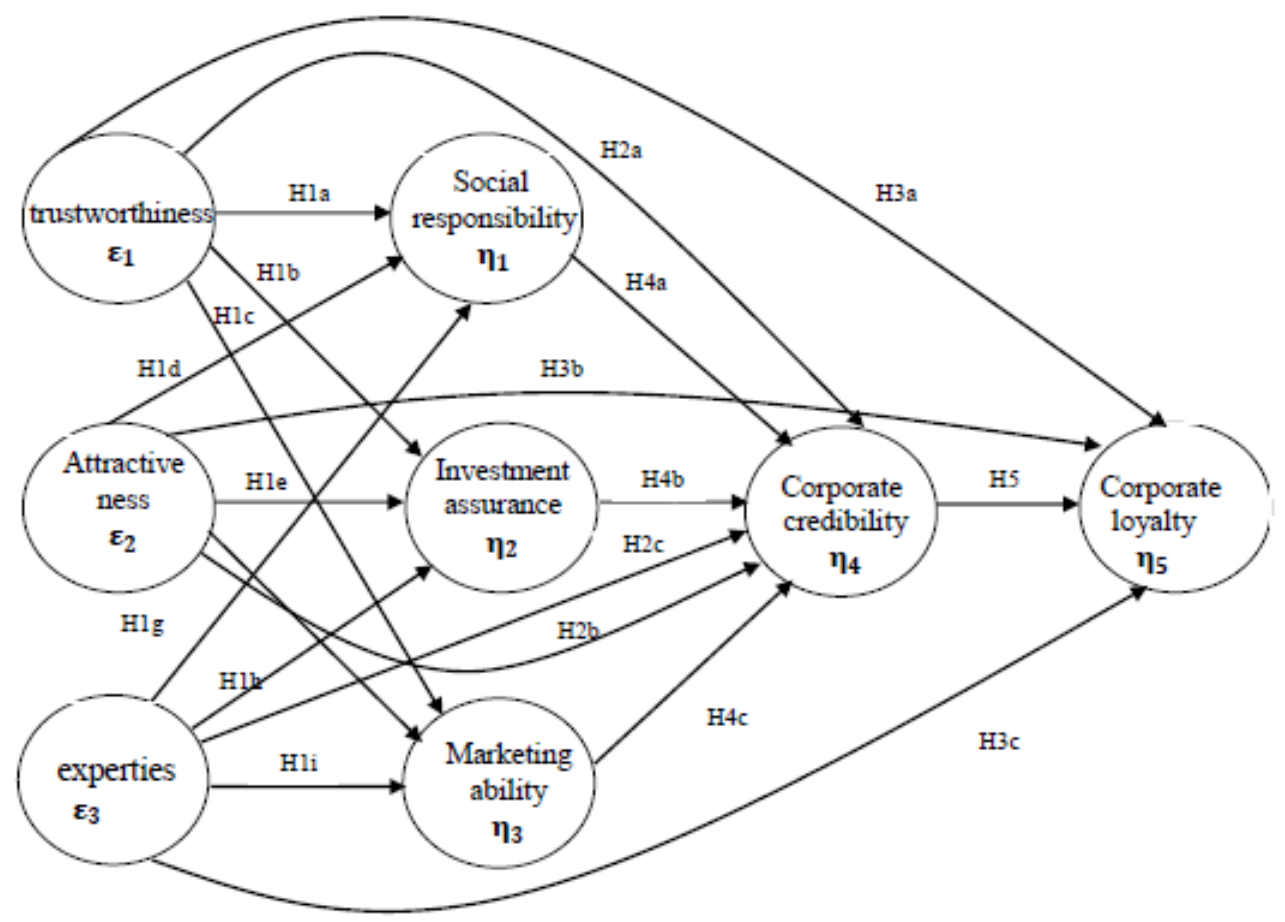

\section{Theoretical Models on the Research}

\subsection{The ABC Model of Attitudes and Herarachy of Effects}

Solomon describes the The ABC model of attitudes as a multidimensional perspecitive stating that attitudes are jointly defined by affect, behaviour and cognition. Affect refers to the way a consumer feels about an attitude object. Behaviour involves the person's intentions to an attitude object. Cognition refers to the beliefs a consumer has about an attitude object. This model emphasizes the interrelations among knowing (cognition), feeling (affect) and doing (behaviour). 


\subsection{Meaning Transfer Model}

McCracken (1989) brings up the meaning transfer model, which is a rich and comprehensive description over the endorsement process. The central premise of the meaning transfer model is that a celebrity encodes a unique set of meaning that can, if the celebrity is well used, be transferrd to the endorsed product. The model is divided into three stages: culture, endorsement and consumption.

\subsection{The TEARS Model}

Shimp (2003) writes that there are two general attributes, credibility and attractiveness that play in important role in facilitating communication effectively. These attributes are also important when it comes to determining how effective an endorser may be. The $\mathrm{T}$ in the TEARS model refers to being seen as belivable, dependable and someone who can be trusted. The E component of the TEARS model refers to expertise. The expertise is about having specific skills, knowledge or abilities that can be related to the endorsed brand. The A component in the TEARS model attractiveness is a key consideration in many endorsement relationship. Respect is the $\mathrm{R}$ in the TEARS model and represents the quality of being admired due to one's personal qualities and accomplishment. Attractiveness is the $\mathrm{S}$, which is similary. This refers to how the endorser matches with the audience in term of age, gender, ethnicity, social class ect.

Dan Hal Din (1999) has examined effect of three external factors on advertisements in evaluation of the brand name. These factors include third party certification, sponsorship of events, brand reputation. This study indicated that use of third party certification has largely affected the variables of product and brand image. Hence, third party certification can be understood as a display of quality of product. Goldsmith et al. (2000) have evaluated effect of third party certification and corporate trust on the attitude towards advertisement, brand name and purchase motivations. In this study, 152 individuals who have observed Mobile Oil pre-purchase were put into question. Results of this study indicated that trust on third party certification has the highest effect on the attitude towards advertisements, yet trust on company has the highest effect on attitude towards brand name. In addition, findings indicated that trust on company plays a major role in consumers' response to advertisements and brand name.

Mohammadali Abdolvand\& Ali Hosseinzade Imam (2014) evaluated and prioritized the components affecting acceptance of celebrities in advertisements in point of view of consumer. Results of this study concerning consumers' motivation indicated persuasion of these individuals in consumer's purchase behavior. Rest of results indicate that increasing extent of sale will not come to realize under employing these individuals, indicating that these individuals must be considered as a means for sale in marketing mix rather than the marketing aims.

\section{Research Method}

The present research is an applied research type, because it examines impact of celebrity endorsement on the consumer perception of corporate image, corporate credibility and 
corporate loyalty. Further, the present research has been categorized as a survey in sake of nature and how to acquire the required descriptive data, and a certain research type in sake of data certainty. The personality characteristics (trustworthiness, expertise and attractiveness) of the celebrity have been considered as the independent variables. Company loyalty is the dependant variable; and corporate image (social responsibility, investment assurance, marketing ability) and corporate credibility are the intervention variables. In this study, library and field studies have been used. The statistical population consists of all the consumers of leather clothes throughout Tehran. In this study, clustering sampling is used, that 22 districts of Tehran in form of five clusters in north, south, east, west and center were considered to determine the clusters. Hence, the non-probability sampling method was used, mentioned that sample group consist of all the Leather Clothing Buyers who used to purchase from the modern leather stores around Tehran.

\subsection{Determination of Sample Size}

In this study, as there are qualitative ordinal variables, the formula below has been used to determine the sample size. Considering maximum variance (0.25) and error (0.05) at confidence level (95\%), the sample size can be calculated through the formula below:

$$
\mathrm{n}=\frac{Z_{\alpha / 2}^{2} \times p \times q}{\varepsilon^{2}} \quad \mathrm{p}=1 / 2=0.5 \mathrm{Z} \mathrm{\alpha} / 2=1.96
$$

With regard to the data above, the selected sample size will be as follows:

$$
\mathrm{n}=(1.96)(1.96) *(0.5)(0.5) /(0.05)(0.05) \_384
$$

\subsection{The Instruments and Method for Data Collection}

Questionnaire was used to collect data. The questionnaire consists of 32 questions, All items measuring celebrity attributes, corporate image, corporate credibility and corporate loyalty were measured on a 5- point Likert-type scale where 1 = "strongly disagree", 3 = "neutral", 5 $=$ "strongly agree". The questionnaires were distributed among those who have witnessed the clothing advertisement by celebrities at Novin leather purchasing centers and the ones who intended to fill the questionnaire in a period of three month. Value of Cronbach's Alpha was obtained equal to 0.920 with the presumption on 30 members in the sample group. The first section asked for respondent's socio demographic details, Section two examined celebrity attributes, section three examined corporate image, section four contained items related to corporate credibility and section five related to corporate loyalty. All question items were designed to measure the effectiveness of the celebrity that respondents selected as their preferred choice.

\subsection{Data Analysis}

Structural Equation Modeling (SEM) was used to asses if the hypothesized theoretical model was consistent with the collected data for all three celebrity cohorts. In this research, the data were analyzed using inferential statistical method, and structural equation modeling (SEM) and confirmatory factor analysis using LISREL 8.8 and SPSS 21.0 were used. 


\section{Results}

\subsection{Overview of Demographic Results of Customers}

A total of 384 sample, 174 person are men and 200 person are women; 103 persons are at the age group under 25 years old, 109 person are at the age group 25-35 years old, 41 person are at the age group 35-45 years old, 20 person are at the age group 45-55 years old and 18 person are at the age group above 55 years old; 154 person are married and 206 person are single; 149 persons have diploma and under diploma, 161 person have bachelor degree, 56 person have master degree and 8 person have Phd.

\subsection{Overview of the Results from Research Hypotheses}

Using Friedman test, ranking the importance level of each of eight variables of research has been considered. Therefore the output of Friedman test, the first priority is given to attractiveness. The next priorities have been given to expertise and investment assurance. On the other hand, the least priority is given to social responsibility. After investigating the research hypotheses, twelve hypotheses have been rejected among nineteen hypotheses in this study, and the seven of hypotheses have been confirmed.

Table 1. SEM analysis for the main hypothesis

\begin{tabular}{lllll}
\hline Hypotesis & Item & $\beta$ & T - value & Decision \\
\hline Hypotesis 1 & Celebrity endorsement-corporate image & 0.35 & 7.24 & accept \\
Hypotesis 2 & Celebrity endorsement-corporate credibility & .30 & 7.31 & accept \\
Hypotesis 3 & Celebrity endorsement-corporate loyalty & 0.21 & 4.73 & accept \\
Hypotesis 4 & corporate image-corporate credibility & 0.47 & 11.41 & accept \\
Hypotesis 5 & corporate credibility-corporate loyalty & 0.53 & 12.11 & accept \\
\hline
\end{tabular}

Table 2. SEM analysis for the sub hypothesis

\begin{tabular}{lllll}
\hline Hypotesis & Item & $\beta$ & T - value & Decision \\
\hline Hypotesis 1a & Trustworthiness-social responsibility & 0.09 & 1.42 & reject \\
Hypotesis 1b & Trustworthiness-Investment assurance & 0.12 & 1.80 & reject \\
Hypotesis 1c & Trustworthiness-Marketing ability & 0.23 & 3.54 & accept \\
Hypotesis 1d & Attractiveness-social responsibility & 0.06 & 0.73 & reject \\
Hypotesis 1f & Attractiveness-Investment assurance & 0.11 & 1.31 & reject \\
Hypotesis 1g & Attractiveness-Marketing ability & 0.01 & 0.17 & reject \\
Hypotesis 1h & Experties-social responsibility & 0.22 & 3.15 & accept \\
Hypotesis 1i & Experties-Investment assurance & -0.07 & 0.93 & reject \\
Hypotesis 1j & Experties-Marketing ability & 0.17 & 2.47 & accept \\
Hypotesis 2a & Trustworthiness-Corporate credibility & 0.05 & 0.93 & reject \\
Hypotesis 2b & Attractiveness-Corporate credibility & 0.01 & 0.15 & reject \\
Hypotesis 2c & Experties-Corporate credibility & 0.26 & 4.68 & accept \\
\hline
\end{tabular}


Hypotesis $3 \mathrm{a}$

Hypotesis $3 b$

Hypotesis $3 \mathrm{c}$

Hypotesis $4 \mathrm{a}$

Hypotesis $4 \mathrm{~b}$

Hypotesis 4c

Hypotesis 5
Trustworthiness-Corporate loyalty

Attractiveness-Corporate loyalty

Experties-Corporate loyalty

social responsibility-Corporate credibility

Investment assurance-Corporate credibility

Marketing ability-Corporate credibility

Corporate credibility-Corporate loyalty

\section{Suggestions from the Researcher's Experiences}

In the present research in the society and in Tehran, seven hypotheses were confirmed among nineteen hypotheses of research.

Among three personality dimensions of celebrity's endorsement, trustworthiness have a major role in corporate image, expertise have a major role in corporate credibility, marketing ability have a major role in corporate credibility and finally corporate credibility have a major role in corporate loyalty. In addition to this study, previous studies also confirmed that the companies must pay attention into such variables to introduce their products by celebrities in their advertisements. It suggested to the company to employ celebrity endorsement to introducing the goods, services, guarantee and warranty and use the celebrities' personality characteristics in customer-orientation. Also, an increasing attention must be into the social responsibility of the company such as an emphasis on customer-orientation and support from consumers through employing the celebrities in the advertisements, that the company must pay attention into the customer support policies. Providing reliable information by the company to consumers is tangible, for which the company makes an attempt to provide accurate information by the celebrity, because if consumers receives any wrong information from the celebrity endorsement, this will cause him distrusting the company. Further, by giving reliable information to the customers and using customers' tastes and preference, the provide for mutual benefit will come to realize and also provide for future growth in the market. Companies should pay attention to in charity's activities and exercise program and propose such activities in their advertisements by employing celebrities who is respectable and reliable for consumers. A particular attention must be protection from the environment and avoidance from the damages to the environment by the company. The company must adhere to the ethical principle and customer-orientation. The celebrities should recognize the difference between the current product and the same products provided for the consumer. The celebrity should use the company products to create sense of trust. The celebrity should attend in the company's advertisement programs and make relationship with the consumers, through which the celebrity will enable to transfer his sense of trust to the consumers and stimulate them to purchase the products of company, causing word-of-mouth advertisement among people.

Company with an emphasis on the attractive features of the celebrity, the company makes an attempt to transfer the concepts of social responsibility through the attractiveness of the celebrity who is employed in the advertisements, e.g., the company is an endorser for the 
sports competitions and can represent the attractive features of the celebrity by giving the memorial statue to the volleyball players.

Sale marketers and planners should seek creating an advantage in the product and services which have been provided to the consumers.

It is a good idea to select a person with the associated expertise or knowledge in advertisement of the goods. Selection of celebrities with associated knowledge and experience results in increasing the individuals' tendency for products of company and also increasing sale. The celebrities with expertise can introduce the company's manufacturing products as the most suitable products in view of the consumers. It is suggested to the companies to pay attention into the social responsibility and customer's expectations about a special feature of a product in order to build a strong image in the consumer's perceptions, because corporate image represents an image of the company in customer's mind. Business thinking for employing the celebrities such as a competition creates between them. It is suggested employing the celebrity as a confirmation expert rather than an advertiser. An expert has increasing power of influence in people's mind because he knows about products and knows about the quality of products and production process. The advertisements of product using the feature of the celebrity's attractiveness must be in a way that the consumer feels that he/she will have a special place by purchase and use of this product in the community. In viewpoint of an Iranian consumer, the advertisements are not affiliated to quality that the consumer must trust the company and features of the manufacturing good so as to cause the loyalty to the company. Using the research and development processes, the company must provide new and fashionable products for the consumers and examine their purchase behavior, so the company must introduce itself as an authentic company in the industry. Further, it is suggested to the company to increase its profitability by supply of new products so as to persuade the consumers to purchase and invest in the company. The company should increase the sale network and the number of stores as much as possible, because company extensiveness rises building a strong image from the company in consumer's mind, leading to increase of trust on the company. The company must provide those products which raise superiority and effectiveness of cost and build sense of valuation in the customers and remove their needs and expectations. Updated manufacturing products in the company causes building trust and loyalty to the company, so it can remove the consumers' needs based on their tastes and preferences. It is suggested providing information on how to use and keeping the products in broacher at stores for the customers increase trust and loyalty to company and increase the profitability of company through increasing the number of customers and increasing the number of purchase by the current customers.

\section{Conclusion}

In Iranian community, due to new trends in marketing strategies including employing celebrities in advertisement programs on one hand as well as some legal barriers in employing these individuals on the other hand, the consumers have not already set a close relationship with such advertisement with a high trust. Accuracy of this subject can be witnessed in disapproval twelve hypotheses from the celebrity's model because the results of 
related research in the other forein communities have different priorities and preferences.

The results indicate that there is a heterogeneous relationship between three characteristics of a celebrity and corporate image and corporate credibility. For example, expertise of a celebrity can create corporate credibility among the consumers, but honesty and attractiveness of the celebrity has no significant effect on consumers' credibility on company.

Firstly, the company requires specifying a specific market as a target market. Then, specifying the characteristics of a celebrity endorsement and finding a celebrity that may be effective in promotion of products, then he/she assist for achieving the favorable aims of company. In most cases, more than one celebrity may be required for covering the entire target market. Enterprises must identify a celebrity who can cover the entire target market, giving priority to employing more than one celebrity in their marketing program. The results indicate that the individuals have a different understanding from the characteristics of a celebrity endorsement. Differences might manifest in case there are different cultures between the consumers and celebrities. Based on previous research in various industries, in which the cultural area of celebrities has been proposed as an effective factor in their ability to attract the consumer. Moreover, the results indicate that there is a special concept for selection of celebrities and their communication tools, especially when the marketers consider the multi-cultural differences in their marketing programs if considering advertisement programs in other communities. In the current era concerning the role of consumers, the marketers aim to use individuals' ability to increase sale or change strategy for increasing the consumers' trust on company. Celebrities' persence can be evaluated as a stimulant rather than a marketing aim; therefore industrialists must pay a particular attention to this issue that the celebrities must be employed as a tools and stimulant in design of advertisement programs with other programs.

\section{References}

Abdolvand, A., \& Hosseinzadeh, E. A. (1393). Evaluating and Prioritizing Effective Factors in Selecting Celebrity Endorsements for Advertising Campaigns from the Consumers' Point of View. Journal of Marketing Management, 23.

Amini, A., Darani, M., Afshani, M., \& Amini, Z. (2012). Effectiveness of marketing strategies and corporate image on brand equity as a sustainable competitive advantage. International Journal of Contemporary Research in Business, 4(2), 192-205.

Amos, C., Holmes, G., \& Strutton, D. (2008). Exploring the relationship between celebrity endorser effects and advertising effectiveness. International Journal of Advertising, 27(2), 209-234.

Ang, L. (2007). Changing Brand Personality through Celebrity Endorsement. Dunedin, N. Z: University of Otago. [Online] Available: http://conferences.anzmac.org/ANZMAC2007/papers/Ang_1.pdf

Blishak, S. A. (2007). Improving Your Company Image. Course Technology PTR, NewYork City. 
Bos, B. (2007). The Image of a Company. PhaidonInc Ltd, New York City.

Carlson, B., \& Donavan, D. (2008). Concerning the effect of athlete endorsements on brand and team-related intentions. Sport Marketing Quarterly, 17, 154-162.

Chang, J., Wall, G., Tsai, C. T. (2005). Endorsement advertising in aboriginal tourism: an experiment in Taiwan. International Journal of Tourism Research, 7, 347-356. http://dx.doi.org/10.1002/jtr.541

Chu, C., \& Chang, C. (2012). The Effect of Advertisement Frequency on the Advertisement Attitude-The controlled Effects of Brand Image and Spokesperson's Credibility. International Conference on Asia Pacific Business Innovation and Technology Management.

Eltom, H. (2006). The celebrity endorsement branding. Bachelor's Thesis, Business Studies, Södertörn University College. [Online] Available: sh.diva-portal.org/smash/get/diva2:15406/FULLTEXT01

Ewin, R. (1993). Corporate loyalty: its objects and its grounds. Journal of Business Ethics, 12, 387-396. http://dx.doi.org/10.1007/BF00882029

Farrell, K., Karels, G., Montfort, K., \& McClatchey, C. (2000). Celebrity performance andendorsement value: the case of Tiger Woods. Managerial Finance, 26(7), 1-15. http://dx.doi.org/10.1108/03074350010766756

Fatt, J., Wei, M., Yuen, S., \& Suan, W. (2000). Enhancing corporate image in organizations. Management Research News, 23(5/6), 28-54. http://dx.doi.org/10.1108/01409170010782037

Fink, J., Parker, H., Cunningham, G., \& Cuneen, J. (2012). Female athlete endorsers: determinants of effectiveness. Sport Management Review, 15, 13-22. http://dx.doi.org/10.1016/j.smr.2011.01.003

Flavian, C., Torres, E., \& Guinaliu, M. (2004). Corporate image measurement: a further problem for the tangibilization of Internet banking services. International Journal of Bank Marketing, 22(95), 366-384. http://dx.doi.org/10.1108/02652320410549665

Fryxell, G., \& Wang, J. (1994). The Fortune corporate 'reputation' index: reputation of what? Journal of Management, 20(1), 1-14. http://dx.doi.org/10.1177/014920639402000101

Grocer, S. (2009). How Tiger Woods destroyed \$12 billion of stock-marketvalue. Wall Street Journal.

Han, E., \& Ki, E. (2010). Developing a measure of celebrity reputation. Public Relations Review, 36(2), 199-201. http://dx.doi.org/10.1016/j.pubrev.2009.10.013

Kanibir, H., \& Nart, S. (2009). Investigating drivers of choice behavior: corporate image, perceived risk and trust interactions through reputation management. Journal of Global Strategic Management, 5, 121-134.

Ketchen, Jr., D. J., Adams, G., \& Shook, C. (2008). Understanding and managing CEO celebrity. Business Horizons, 51, 529-534. http://dx.doi.org/10.1016/j.bushor.2008.06.003 
Kim, S., Agrusa, J., Lee, H., \& Chon, K. (2007). Effects of Korean television dramas on theflow of Japanese tourists. Tourism Management, 28(6), 1340-1353. http://dx.doi.org/10.1016/j.tourman.2007.01.005

Kim, S., Lee, J., \& Prideaux, B. (2014). Effect of celebrity endorsement on tourists' perception of corporate image, corporate credibility and corporate loyalty. International Journal of Hospitality Management, 37, 131-145. http://dx.doi.org/10.1016/j.ijhm.2013.11.003

Kim, S., Wang, G., \& Ahn, T. (2013). Which endorser and content are most influential in Korean restaurant promotions? International Journal of Hospitality Management, 33, 208-218. http://dx.doi.org/10.1016/j.ijhm.2012.08.005

Kim, W., \& Kim, H. (2004). Measuring customer-based restaurant brand equity. Cornell Hotel and Restaurant Administration Quarterly, 45(2), 115-131. http://dx.doi.org/10.1177/0010880404264507

Kotler, P. H., \& Foroozandeh, B. (1385). Marketing management. Isfahan: Amookhteh Publishing House.

Lafferty, B., \& Goldsmith, R. (1999). Corporate credibility's role in consumers' attitudes and purchase intentions when a high versus a low credibility endorser is used in the ad. Journal of Business Research, 44(2), 109-116. http://dx.doi.org/10.1016/S0148-2963(98)00002-2

Lee, S., Scott, D., \& Kim, H. (2008). Celebrity fan involvement and destination perceptions. Annals of Tourism Research, 35(3), 809-832. http://dx.doi.org/10.1016/j.annals.2008.06.003

Lee, S., Singal, M., \& Kang, H. (2013). The corporate social responsibility-financial performancelink in the U.S. restaurant industry: do economic conditions matter? International Journal of Hospitality Management, 32, 2-10. http://dx.doi.org/10.1016/j.ijhm.2012.03.007

Lemmink, J., Schuijf, A., \& Streukens, S. (2003). The role of corporate image and company employment image in explaining application intentions. Journal of Economic Psychology, 24, 1-15. http://dx.doi.org/10.1016/S0167-4870(02)00151-4

Lin, C., Wang, K., \& Chen, W. (2008). Female tour leaders as advertising endorsers. Service Industries Journal, 28(9), 1265-1275. http://dx.doi.org/10.1080/02642060802230239

Lin, L., \& Lu, C. Y. (2010). The influence of corporate image, relationship marketing and trust on purchase intention: the moderating effect of word of mouth. Tourism Review, 65(3), 16-34. http://dx.doi.org/10.1108/16605371011083503

Lord, K., \& Putrevu, S. (2009). Informational and transformational responses to celebrity endorsement. Journal of Current Issues and Research in Advertising, 31(1), 1-13. http://dx.doi.org/10.1080/10641734.2009.10505253

Magnini, V., Garcia, C., \& Honeycutt, E. (2010). Identifying the attributes of an effective restaurant chain endorser. Cornell Hospitality Quarterly, 51(2), 238-250. 
http://dx.doi.org/10.1177/1938965510363669

Magnini, V., Honeycutt, E., \& Cross, A. (2008). Understanding the use of celebrityendorsers for hospitality firms. Journal of Vacation Marketing, 14(1), 57-69. http://dx.doi.org/10.1177/1356766707084219

Muda, M., Musa, R., \& Putit, L. (2012). Breaking through the Clutter in Media Environment: How Do Celebrities Help? Social and Behavioral Sciences, 42, 374-382. http://dx.doi.org/10.1016/j.sbspro.2012.04.201

Ohanian, R. (1991). The impact of celebrity spokespersons' perceived image on consumer's intention to purchase. Journal of Advertising Research, 31(1), 46-54.

Sekaran, O., \& Shirazi, M. (1386). Research Methods in Management. Institute of Management and Planning Publishing House.

Solomon, M., Bamossy, G., \& Askegaard, S. (2002). Consumer behaviour: A European perspective (2nd ed.). UK: Prentice Hall Europe.

Stallen, M., Smidts, A., Rijpkema, M., Smit, G., Klucharev, V., \& FernUndez, G. (2010). Celebrities and shoes on the female brain: the neural correlates of product evaluation in the context of fame. Journal of Economic Psychology, 31(5), 802-811. http://dx.doi.org/10.1016/j.joep.2010.03.006

Stephens, N., \& Faranda, W. (1993). Using employees as advertising spokespersons. Journal of Services Marketing, 7(2), 36-46. http://dx.doi.org/10.1108/08876049310038391

Till, B., \& Busler, M. (2000). The match-up hypothesis: Physical attractiveness, expertise, and the role of fit on brand attitude, purchase intent and brand beliefs. Journalof Adverting, 29(3), 1-13. http://dx.doi.org/10.1080/00913367.2000.10673613

Tripp, C., Jensen, T., \& Carlson, L. (1994). The effects of multiple product endorsementsby celebrities on consumers' attitudes and interests. Journal of ConsumerResearch, 20(March), 535-547. http://dx.doi.org/10.1086/209368

van der Veen, R. (2008). Analysis of the implementation of celebrity endorsement as a destination marketing tool. Journal of Travel \& Tourism Marketing, 24(2/3), 213-222. http://dx.doi.org/10.1080/10548400802092841

Wang, H., \& Doong, H. (2010). Argument form and spokesperson type: the recommendation strategy of virtual salespersons. International Journal of Information Management, 30(6), 493-501. http://dx.doi.org/10.1016/j.ijinfomgt.2010.03.006

Wang, K. C., Hsieh, A. T., Chen, W. Y. (2002). Is the tour leader an effective endorserfor group package tour brochures? Tourism Management, 23, 489-498. http://dx.doi.org/10.1016/S0261-5177(02)00004-3 


\section{Copyright Disclaimer}

Copyright for this article is retained by the author(s), with first publication rights granted to the journal.

This is an open-access article distributed under the terms and conditions of the Creative Commons Attribution license (http://creativecommons.org/licenses/by/3.0/). 